Article

\title{
Prototyping of a Novel Rammed Earth Technology
}

\author{
Giada Giuffrida*D, Rosa Caponetto, Francesco Nocera (D) and Massimo Cuomo
}

Department of Civil Engineering and Architecture, University of Catania, 95125 Catania, Italy; rosa.caponetto@unict.it (R.C.); francesco.nocera@unict.it (F.N.); mcuomo@dica.unict.it (M.C.)

* Correspondence: giada.giuffrida@unict.it

check for updates

Citation: Giuffrida, G.; Caponetto,

R.; Nocera, F.; Cuomo, M.

Prototyping of a Novel Rammed

Earth Technology. Sustainability 2021,

13, 11948. https://doi.org/10.3390/ su132111948

Academic Editors: Marc A. Rosen and Antonio Caggiano

Received: 26 July 2021

Accepted: 26 October 2021

Published: 28 October 2021

Publisher's Note: MDPI stays neutral with regard to jurisdictional claims in published maps and institutional affiliations.

Copyright: (c) 2021 by the authors. Licensee MDPI, Basel, Switzerland. This article is an open access article distributed under the terms and conditions of the Creative Commons Attribution (CC BY) license (https:// creativecommons.org/licenses/by/ $4.0 /)$.

\begin{abstract}
Buildings of the future are called to meet increasingly high-performance requirements and to ensure adequate environmental sustainability of the production and construction chain. This issue has stimulated a keen interest in the use of natural materials in construction. Among these, raw earth has proved to be particularly interesting for its intrinsic availability, sustainability, and recyclability. In Europe, the spread of raw earth building technologies has often been hindered by the lack of specific legislation regulating its use for load-bearing structures, even if in many countries, it can be noticed a widespread and well-established constructive tradition. Some transoceanic research experiences attest that unfired earth can be used, together with different types of reinforcements, to create seismic-resistant buildings. After presenting a review of the main raw earth reinforced technologies, the present study focuses on a novel reinforced and modular rammed earth construction made with natural or recycled materials, developing a technology with low energy consumption and low environmental impact, specifically designed for areas with high seismic risk. In particular, the work presents the results of a prototyping procedure aiming at developing a new seismicresistant construction system that combines rammed earth with timber reinforcement elements and nylon/polyester ropes. These elements have a dual function: (1) they are fundamental components of the construction process (as they integrate the formwork system), and (2) they act as seismic-resistant devices once the structure is completed. In line with the performance-based approach required by the construction sector, the study aims at defining a controlled and standardised supply chain for rammed earth construction.
\end{abstract}

Keywords: rammed earth construction; prototyping; production and constructive process; seismic resistance; thermal performance

\section{Introduction}

In line with international and European directives [1,2], the construction sector today must respond to a series of new demands, being the most pressing those concerning the reduction in available resources, the containment of energy consumption and the abatement of $\mathrm{CO}_{2}$ emissions. Buildings based on the use of natural building materials have attracted international attention in response to the current energy crisis and the deterioration of the world's natural environment. Raw earth as a building material is taking on new importance due to its availability, lack of toxicity, recyclability, low energy incorporated in the manufacturing/production phase and good thermo-hygrometric and acoustic performance.

At the same time, the construction sector today, especially in western industrialised countries, requires performance-based design (and therefore quantitative guarantees of the expected performances), which the raw earth construction sector does not currently have. Therefore, starting from the desire to renew the tradition of using natural and sustainable materials, the construction market is called upon to offer economic, sustainable products that are also certifiable following a controlled and standardised supply chain.

In the context of new construction, solid rammed earth building systems (also in combination with reinforcing framed structures) have undoubted environmental benefits and 
high thermal performance in temperate climates, such as the Mediterranean, characterised by a large thermal oscillation between day and night. The high thermal mass, and therefore, the inertia of these building envelopes, stabilises and balances the internal temperatures and humidity of the buildings, ensuring internal comfort conditions [3,4]. In addition, rammed earth envelopes have high fire resistance and excellent acoustic characteristics.

The present study focuses on a novel type of reinforced and modular rammed earth construction made with natural, low-cost or recycled materials from other production chains to develop a technology with low energy consumption and low environmental impact, specifically designed for areas with a high seismic risk.

The investigated solution differs from current raw earth technologies, which follow two main development paths: the first is more linked to the vernacular knowledge of local labour, characterised by artisanal production and construction methods [5-8], which determine uncertainty about the performances of the material and the building. The second is characterised by the use of industrial materials for structural purposes, with generalised use of steel reinforcements and stabilisation of the soil mixtures using synthetic binders, such as cement $[9,10]$, which could compromise the sustainability of the process and the recyclability of the product.

The proposed system is in an intermediate position, as it maintains the focus on the use of sustainable and recyclable materials and, at the same time, guarantees an adequate and durable response in terms of seismic resistance and thermophysical performance.

\section{State of the Art on Raw Earth Reinforced Technologies}

The bibliographic research on historical and contemporary raw earth constructive technologies was based on scientific publications, traditional construction manuals, commercial technologies, standardised and patented construction systems. The objective of this analysis was to identify the best performing reinforcement systems for raw earth walls. Raw earth walls are usually combined with high-tensile strength functional elements that improve their seismic-resistant behaviour (timber frames, reeds, natural and non-natural fibres nets and ropes, etc.). In the analysis, a series of information concerning the studied technologies are provided:

- the name, the geographic location and the indication of when the system was adopted;

- the constructive process used (in situ, prefabricated or partially prefabricated);

- the composition of the loadbearing structure (type of walling structure, type of adopted reinforcing elements, number and position of reinforcing elements with reference to the cross-section of the walls, materials used);

- type of floors;

- $\quad$ anti-seismic devices adopted, if any;

- thermal improvements adopted, if any;

- connection details, if detailed.

Among the historical building systems, including stone masonry, the construction principles of the Baraccate Houses (Italy), the Pombalino System (Portugal), the Himıs System (Turkey) and the Lefkada Islands system (Greece) have been studied. These construction systems, many of which have been developed from the opus craticium adopted in Roman provinces [11], have shown excellent resistance to real seismic events. In the last few years, numerous studies have aimed at their structural modelling. In all historical systems, it is possible to identify the following anti-seismic strategies:

- connections between orthogonal walls (by means of ring beams or ties);

- the lowering of the centre of gravity of the building (by using heavier material at the ground floor, and lightweight ones at superior floors);

- the increase in the deformability of the walls (by the addition of high tensile strength materials or reinforcements);

- the reduction in the structure's weight (by the addition of lightweight materials as aggregates or reinforcements). 
The system of the Baraccata house, widespread in several Italian regions (Basilicata, Campania, Calabria, and Sicily), consists of a stone or adobe masonry reinforced by a timber frame. The latter is composed of horizontal, vertical and oblique elements, which are riveted together and act as bracing, with a cross-section between 10 and $12 \mathrm{~cm}$. This reinforcing system allows for good box-like behaviour of the masonry [12]. This construction system has been subjected to cyclical in-plane tests in the framework of research by CNR-Ivalsa and the University of Calabria [12], scientifically demonstrating the validity of this construction scheme in the dissipation of seismic energy and in the acquisition of greater ductility (provided by the timber framing) and resistance (provided by the masonry).

A similar analysis was carried out on the Gaiola Pombalina system, adopted in Lisbon after the 1755 earthquake, a construction system characterised by the adoption of shear walls made with a continuous timber frame for all the floors of the building and to which the timber floors are anchored. The timber frame is composed of non-deformable triangles that form a three-dimensional stiffening structure that performs well under static and dynamic loads; the fields between one timber element and the other are filled with various material (limestone blocks, bricks, mortar), which give ductility to the structure, increase the energy dissipated in the earthquake event and the cyclical rigidity, as demonstrated by $[13,14]$.

The construction system developed in the Greek Lefkada islands adopted a masonry ground floor coupled with an auxiliary structural timber system located on the inner side of the wall; the lightweight timber-framed structure of the upper floor lies on these two structural systems [15].

Finally, the Turkish Hımıs construction system follows the scheme of the Ottoman houses, providing a massive stone masonry on the ground floor, combined with timber ring beam, while on the upper floors, the lightweight walls are composed of timber frames filled with bricks and/or adobes [16].

As far as contemporary construction is concerned, most technologically advanced countries such as Europe, North America and Oceania offer rather homogeneous technological solutions for raw and rammed earth construction, with the use of vertical steel reinforcement for the walls, connected to a top and a bottom concrete beam. This reinforcement guarantees a seismic-resistant behaviour $[17,18]$.

Among raw earth construction techniques, rammed earth (and its prefabricated variant) and compressed earth blocks constitute the largest slice of contemporary production. Lehm Ton Erde's experience [19] has breathed new life into earth construction in Europe, but it has rarely been adopted in areas characterised by seismic risk and only in combination with metal reinforcement. A similar approach has been used by David Easton in Watershed Materials: compressed earth blocks using concrete masonry units technology and reinforced with steel bars [20]. Another interesting solution is the one presented by Sirewall [21], which uses a patented formwork for the realisation of a cavity rammed earth wall, cement stabilised and reinforced with steel rods that are connected by brackets. Two wythes of the rammed earth wall surround a layer of polyisocyanurate insulation to create a seismic-resistant wall with high thermal performance.

A similar system is described both in New Zealand Building Code [22] and in the American Reinforced Cob Standard [23]. Both these codes describe reinforced and stabilised earth walls built with horizontal (steel brackets or grid) and vertical steel rebar reinforcement if needed. Walls are well connected by the vertical rebars to the footing and to the bond beam (realised in concrete [22,23] or in timber [22]).

In [24], reinforced rammed earth walls' mechanical behaviour under pseudo-dynamic loading is investigated. Rammed earth walls are strengthened with polyester fabric strips to exploit the compressive strength potential of rammed earth and to solve its lack of tensile strength. In this research, in-plane cyclic tests were carried out to investigate the shear behaviour of unstrengthened and strengthened walls. The proposed strengthening technique requires low-tech equipment and workmanship, easily available, not expensive and industrially standardised materials. The experimental results were analysed in terms of stiffness degradation, energy dissipation capacity and equivalent viscous damping. Although the 
unstrengthened and strengthened walls confirmed a limited ductile behaviour, the findings confirm that the strengthening contributes to limiting the spread of the diagonal cracks and provides an increase in strength in terms of horizontal load and displacement capacity.

On the other hand, between developing countries and with particular attention paid to the South American context, different building systems, both historical and contemporary, have been analysed in territories that are among the most seismic on our planet. Reinforced earthen construction techniques are present throughout South America, as evidenced by the research and dissemination activities carried out by the PROTerra network: from the tabique/bahareque to the Peruvian quincha to the reinforcement systems for adobe and rammed earth masonries [25]. Concerning adobe and rammed earth walls, reinforcement can be internal or external to the wall thickness, with numerous variations that have been refined over time [26].

In Chile, a historical mixed earth-timber system, called tabique-adobillo, was developed beginning in the middle of the 19th century [6] because of the increased quantity of timber entering the port of Valparaiso for the construction of boats. This standardised and modular constructive system presents cruciform timber posts with a reduced cross-section, spaced every $50 \mathrm{~cm}$ as if it were a progenitor of modern platform-frame systems. Moreover, it presents diagonal bracing elements. The fields between these cruciform posts are filled with adobe bricks shaped to fit the section of the posts, improving the acoustic and thermal comfort of the construction. These adobes also contribute to earthquake resistance. A surface reinforcement system, made of iron wire, metal mesh or timber battens, allows counteracting the possible overturning of the adobe bricks.

Still in Chile, work continues the favourable combination of earth filling and timber reinforcement system even in contemporary times, as demonstrated by the development of the patented construction system promoted as "E-Logic Wall" [7]. In this system, a raw earth infill (possibly mixed with wood chips, polystyrene or other materials lowering the thermal conductivity) is confined by a timber structure composed of coupled timber posts and stiffening elements to which a surface reinforcement system (made with timber diagonals) is connected. In this way, the structural box behaviour of the walls is assured.

Other raw earth-based systems using timber $[8,27-29]$ or bamboo $[30,31]$ reinforcing skeleton insist on the importance of adopting timber/bamboo columns in continuity with the raw earth walls but lack detailed connections between these elements in the crosssection of the wall.

All these systems use a top ring beam connected to the vertical reinforcing members.

Peru, one of the few countries that boast research in the field of earthquake-resistant earthen construction, deserves a special mention. In 2017, Peru adopted a new construction standard for reinforced earthen construction [5]. This regulation collects the experiences that have been carried out at Pontificia Universidad Católica del Perú [32] on the effectiveness of different reinforcement systems for earth masonry. In particular, the standard describes at least four types of reinforcement systems among adobe and rammed earth ones. According to the standard [5], adobe masonries can be reinforced by (1) an embedded reeds grid in the wall, with vertical reeds (spaced about $35-40 \mathrm{~cm}$ and connected to horizontal split canes) and horizontal split ones (embedded in the mortar and placed every four adobe rows at the bottom part of the wall, every three at the middle and every two at the top); (2) a geogrid exterior reinforcement that is installed and blocked by flexible cross connectors, with the prevision of an overlapping of the grid, so it works continuously all over the wall; (3) an exterior rope mesh reinforcement composed of vertical and horizontal tensioned ropes that are blocked by rope cross connectors. This last system is also recommended for rammed earth construction. All the reinforced systems presented in the Peruvian Standard also recommend the use of a timber ring beam composed of two longitudinal members and several cross connectors, which must be firmly connected to the reinforcing system of the walls. Moreover, the standard encourages the use of natural and vegetal reinforcements as:

- entire canes (hollow or solid), approximately $25 \mathrm{~mm}$ in diameter as vertical reinforcement and split ones, as internal horizontal reinforcement; 
- timber post with diameters greater than $25 \mathrm{~mm}$ as vertical reinforcement and natural ropes with a minimum diameter of $6 \mathrm{~mm}$ as horizontal reinforcement;

- woven vegetable fibre branches, in packages with diameters of $25 \mathrm{~mm}$ as external vertical reinforcement and loose braided branches or ropes as external horizontal reinforcement, with diameters greater than $6 \mathrm{~mm}$;

- $\quad$ ropes made of natural fibres braided into external orthogonal meshes.

\section{Design Proposal and Methods}

\subsection{Multiphase Prototyping}

A design-simulation-validation approach, characterised by several design iterations, has been carried out. Prototyping and validation procedures were used for designing the reinforced and modular constructive technique and building process. Particularly, the first design of the constructive system was carried out at the Centro Tierra of the Pontificia Universidad Católica de Peru, the main formulator of the Standard E 080-Diseño y construcción con tierra reforzada [5]. According to this standard, the construction system must use at least a solid $40 \mathrm{~cm}$ thick rammed earth wall and the building characteristics (wall's height, spacings between loadbearing elements, voids width) must respect specific features, as shown in Table 1; finally, the rammed earth walls must present a reinforcement system according to those indicated in the previous paragraph.

Table 1. Verification of the preliminary design according to [5].

\begin{tabular}{|c|c|c|c|c|}
\hline Data & Symbol & Value $[\mathrm{cm}]$ & Condition & Verification \\
\hline Raw earth wall thickness & $\mathrm{e}$ & 40 & - & - \\
\hline Buttress Thickness & $\mathrm{e}_{0}$ & 40 & (I) $\mathrm{e}_{0} \geq \mathrm{e}$ & OK \\
\hline Raw earth wall Height & $\mathrm{H}$ & 256 & - & - \\
\hline Spacing Between loadbearing elements & $\mathrm{L}$ & 380 & - & - \\
\hline Voids width & a & 70 & (II) $\mathrm{a} \leq \mathrm{L} / 3$ & OK \\
\hline Distance from the void to the buttress & $\mathrm{b}$ & 155 & (III) $3 \mathrm{e} \leq \mathrm{b} \leq 5 \mathrm{e}$ & OK \\
\hline Horizontal slenderness & $\Lambda_{\mathrm{h}}=\mathrm{L} / \mathrm{e}$ & 9.5 & $\kappa_{\mathrm{h}} \leq 10$ & OK \\
\hline Vertical slenderness & $\kappa_{\mathrm{V}}=\mathrm{H} / \mathrm{e}$ & 6.4 & $\begin{array}{c}\Lambda_{\mathrm{V}} \leq 6 \\
\text { or } 8 \text { if }(\mathrm{IV}) \text { it is verified }\end{array}$ & $\mathrm{OK}$ \\
\hline $\begin{array}{l}\text { Relation between horizontal and vertical } \\
\text { slenderness }\end{array}$ & - & - & $\begin{array}{l}\text { (IV) } \mathrm{L}+1.25 \mathrm{H} \leq 17.5 \mathrm{e} \\
\text { (V) } K_{\mathrm{h}}+1.25 \kappa_{\mathrm{V}} \leq 17.5\end{array}$ & $\begin{aligned} 700 & \leq 700 \\
17.5 & \leq 17.5\end{aligned}$ \\
\hline
\end{tabular}

The first design of our technology involved the use of prefabricated rammed earth panels (produced under controlled conditions in order to ensure a high-quality product) to be used together with a timber reinforcement frame as in $[28,29]$ to improve the overall strength. According to this system, the earthen masonry responds mainly to vertical loads, while the timber elements absorb the bending and shear stresses caused by any earthquakes, increasing the inertia of the cross-section. Moreover, an auxiliar horizontal surface reinforcement made by ropes was adopted to prevent from out of plane mechanisms, as in $[33,34]$.

The construction of a scaled rammed earth model for a qualitative comparative dynamic test helped us in the verification of the constructive system and process. The objectives of the qualitative comparative dynamic test were to compare the qualitative seismic behaviour of reinforced and unreinforced rammed earth models using a portable shake table and to compare the effectiveness of natural and low-cost reinforcements with industrial ones. The adopted qualitative test was already implemented by $[35,36]$ and consisted of the simulation of the qualitative seismic behaviour of different scaled building models, using a portable shake table activated by a bike-type mechanism. The maximum model weight is approximately $80 \mathrm{~kg}$ as the energy to start the test is provided by a man by the bike-type mechanical system.

During the test, three constructive solutions were compared: the traditional and unreinforced rammed earth system realised in situ, the contemporary concrete-reinforced 
rammed earth system realised in situ and a low-cost reinforced prefabricated rammed earth solution (using a timber reinforcing skeleton and an auxiliar rope reinforcement). In particular, the last one represented the first design of our reinforced rammed earth technology. The three modules have been realised on a scale of 1:10. In order to show the typical weakness of raw earth walls when subjected to an earthquake (joints between bricks/blocks, connections between orthogonal walls), Serrano et al. [36] do not use any mortar between the construction elements to discourage the rigid block motion of the models; the same approach was followed during our test. In the first phase of the test, the three modules were put on the top of the portable shake table to be tested simultaneously. In the second phase of the test, small impulses were given to the shake table through the pedals, causing the collapse of the unreinforced rammed earth model right at the beginning. In the third phase of the test, the rigid concrete slab of the concrete reinforced model experienced a higher acceleration and was projected out of the table. The low-cost reinforced prefabricated rammed earth showed cracks in the joints but did not collapse. Three phases of the qualitative comparative dynamic test are shown in Figure 1.
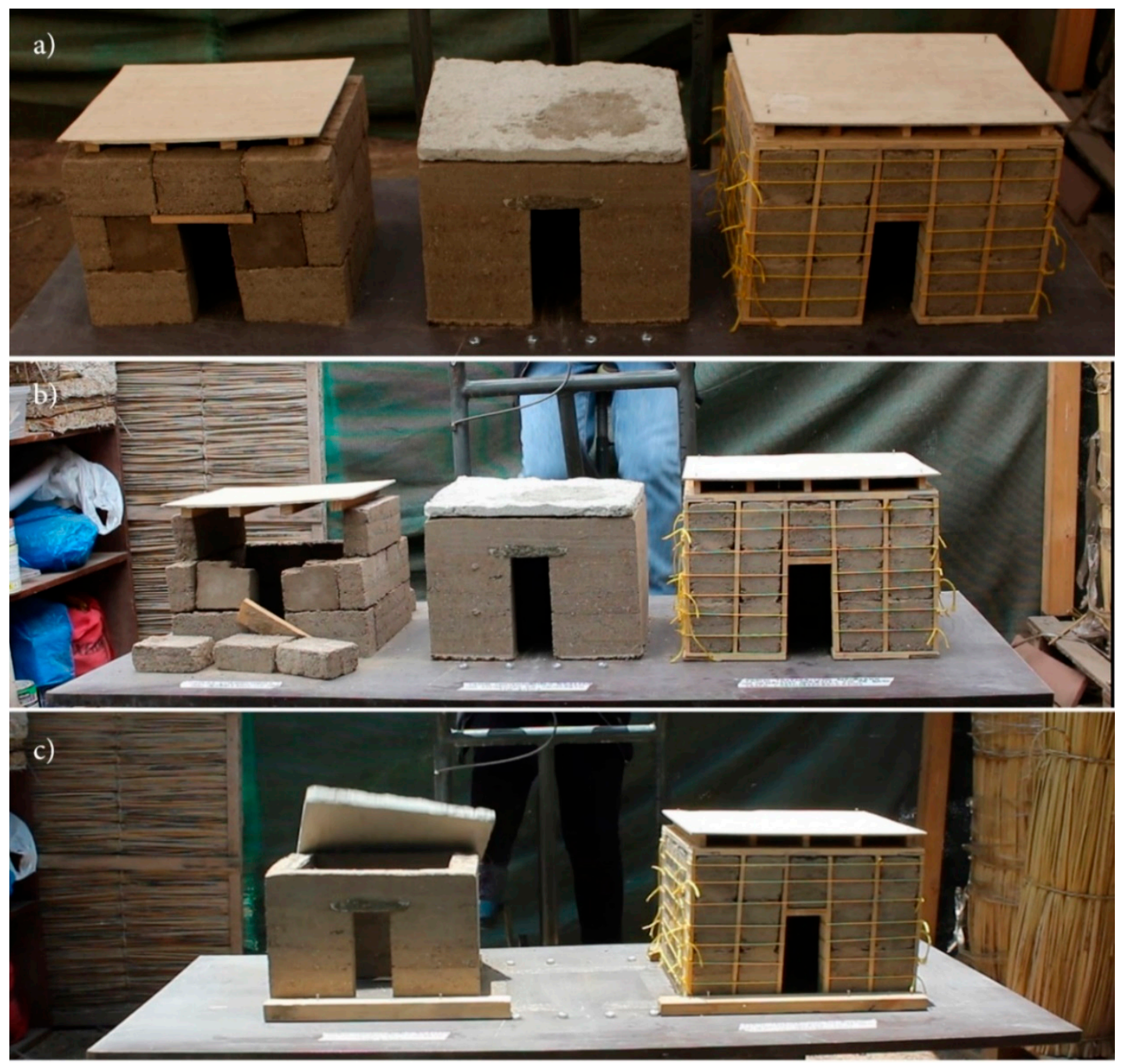

Figure 1. Phases of the qualitative dynamic comparative test: (a) the three models are placed on the shake table; (b) collapse of the unreinforced model; (c) better performance of our technology compared to concrete reinforced model.

The results of this test showed the effectiveness of our seismic-resistant design, but during model preparation, the need to simplify the constructive process was also observed, especially when referring to the installation of rammed earth panels in the reinforced system. For this reason, we abandoned the idea of using prefabricated rammed earth 
panels in favour of on-site built walls, with a controlled earth mix, and reinforced by prefabricated timber elements (posts, ring beams, lintels) and auxiliar rope reinforcement. In this system, the reinforcing timber frame has a dual function: it works as a support element for the formwork during the construction phase, and it acts as a reinforcement for the walls in the event of an earthquake.

The new constructive system and processes were designed and controlled by the construction of several 3D models. Finally, with the help of the industrial partner, a full-scale prototype has been built on the basis of the hypothesised construction phases.

\subsection{Performances Validation}

The performances of the proposed constructive system have been deduced both from the literature review and validation procedures.

The good mechanical performance of the designed rammed earth reinforced constructive system was deduced from several full-scale tests made on rammed earth building models at the Pontificia Universidad Católica de Peru. In particular, the effectiveness of the timber reinforcement system has been proved by the tests realised in [28]: with this kind of reinforcement, the walls can withstand bending moments at least three times higher than the unreinforced walls [29]. As highlighted by the authors, one of the advantages of placing the reinforcement in the walls by connecting it to the wall joints and the foundation is that it allows a greater rigidity to the roof beams, therefore ensuring that the roof behaves as semi-rigid and the floor beams as edges horizontal braces. Another advantage of including a reinforcement to the walls, timber or otherwise, is that if the walls fail during a severe or rare earthquake, failure is not due to slippage in the joints but rather to diagonal traction. The effectiveness of rope reinforcement in earthen buildings has been extensively confirmed with further investigations [37] and by real observations of Lampa's earthquake of 2016 [38], proving that it maintained structural integrity and stability and prevented the partial collapse of wall portions during the motion.

The methodological approach adopted for the evaluation of the thermal performance of the designed solution was:

- design of a rammed earth building based on the innovative constructive system;

- use of bioclimatic design strategies, including use of summer night cross ventilation and overhangs, to optimise comfort conditions and reduce energy needs;

- dynamic thermal simulations on Design Builder software under free-running conditions with the aim of comparing the behaviour of the uninsulated rammed earth building's envelope structure to the insulated one.

The building consists of a rectangular-shaped box, with three rooms facing South and two rooms facing East and West. All the load-bearing rammed earth walls are $40 \mathrm{~cm}$ thick, while the partitions are made of lightweight materials. The stratigraphy of the designed walls, roof and solid ground floor and the characteristics of the materials are reported in [39]. The net internal height of the walls is $3 \mathrm{~m}$, the total envelope area is $825.9 \mathrm{~m}^{2}$, while the gross volume is $261.4 \mathrm{~m}^{3}$. The shape factor is 3.16 , and the net usable area is $58.92 \mathrm{~m}^{2}$. Since the thermal performance of buildings and the influences of thermal mass and passive strategies can only be evaluated through dynamic thermal simulations [40-43], the dynamic thermal behaviour of the representative rammed earth building was analysed using Design Builder software, version 6.0, which is based on the Energy Plus calculation engine. In the Design Builder model, all rooms in the reference residential building were considered as occupied zones. The internal loads are represented by occupants, electrical devices, cooking and lighting systems, which amount to $928 \mathrm{~W}$ with a density of $16 \mathrm{~W} / \mathrm{m}^{2}$. The occupancy power density is $7.00 \mathrm{~W} / \mathrm{m}^{2}$ for an occupancy of 0.05 persons $/ \mathrm{m}^{2}$; the power density of electrical devices and lighting is $5.00 \mathrm{~W} / \mathrm{m}^{2}$ and $4.00 \mathrm{~W} / \mathrm{m}^{2}$, respectively. A constant air exchange of $0.5 \mathrm{~V} / \mathrm{h}$ was set for outside air infiltration. Meteorological data from the Energy Plus Weather (EPW) file for the city of Catania updated to 2019 were used as meteorological input. 
In the first phase of the investigation, different configurations of the simulated building model were proposed to study the effects of different bioclimatic strategies (summer night cross-ventilation, use of overhangs and combined effects) [39]. In the second phase, an accurate thermal dynamic analysis was performed to evaluate and compare the thermal behaviour of a naturally insulated rammed earth building envelope (with a $6 \mathrm{~cm}$ thick cork insulation or a $12 \mathrm{~cm}$ thick lime-hemp plaster) and an uninsulated one in free-running conditions.

\section{Construction and Production Process of the Building System}

The solution investigated, developed together with the local industrial partner Guglielmino Soc. Coop. and currently filed for a patent application [44], consists of a construction system composed of rammed earth walls made with new mixtures of clayey soil and recycled materials from other production chains (natural fibres and filler material), reinforced with seismic-resistant devices consisting of a timber reinforcement framing and nylon/polyester rope ties. This invention envisages the development of a formwork system integrated with the timber stiffening frame, capable of guaranteeing rapid, low-cost and partially prefabricated installation. As mentioned before, the timber frame has a dual function: it is a support element for the formwork during the construction phase, and it acts as a reinforcement structure for the walls in the event of an earthquake. The system is partly manufactured in the factory (with a controlled supply chain in relation to the shape and size of the timber components, constituent mixtures, jointing systems, etc.), and then it is assembled on-site to guarantee the control of the quality of the product, of the process and, therefore, the expected performance response. In the following, we will explore the most significant aspects of the innovations sought in the product and in the construction process of the proposed constructive technology.

\subsection{Base Material}

Concerning the base materials, the proposal foresees the use of a rammed earth premixed material that guarantee precise performances. However, if during the construction phase it is desired to use the soil present in situ (from the footing excavation), it is possible to test the latter, properly cleaned from alterations and intrusions, following a protocol specifically defined to assess the compliance with minimum requirements to ensure the expected performance. The proposed material consists of a fibre-reinforced mixture of inorganic clayey soil, sand, natural fibre and filler material, whose exact composition will be disclosed in a future publication. Each component performs specific tasks and the procedures for the manufacturing of the mixes are particularly important for the final performance.

The first hypothesis involves the use of a rammed earth premixed material whose basic materials are prepared in the factory. Once the premixed material is made, it should be placed in closed, heavy-duty bags for handling. The addition of water takes place on-site, with the help of an axial mixer: a progressive amount of water is added to the premixed material to bring the mixture to a humid state. The amount of water to be added is indicated in the bag and can be between 10 and 13\% of the weight, depending on the workability wanted. The mixture, once well mixed and moistened, must be left to rest under an impermeable fabric to promote more uniform hydration of the material for at least $24 \mathrm{~h}$.

The second hypothesis involves the use of soil quarried in situ. Notwithstanding the use of a percentage of filler and natural fibres for the optimisation of resistance to water absorption and the increase in the ductility of the material, it can be considered the hypothesis of using soil quarried in situ for the construction, reformulating the mixture to obtain physical and mechanical performance of equivalent values to those obtained with the premixed material. This can only be done if the local soil is suitable for rammed earth construction. The operations to be carried out to verify the soil are defined by a protocol specifically developed that will be disclosed, together with the adopted mix, in a future publication. 


\subsection{Constructive System}

As anticipated above, the proposed construction system uses a reinforcing mesh consisting of vertical and horizontal timber elements (posts and ring beams) and horizontal rope elements (nylon/polyester ties). These two reinforcement systems meet two complementary needs. The timber reinforcement system provides an over-strength to the fibre-reinforced rammed earth masonry: in this way, the wall assumes a greater inertia and resistance to shear and bending (due to the presence of timber posts) and is effectively connectedto the foot and head of the wall (due to the presence of the top and bottom timber ring beams). The system of auxiliary reinforcement in ropes allows the control of the displacements of portions of the wall eventually cracked because of stress in the plane: in this way, it is assumed the possibility of formation of cracks in the wall without affecting the safety of the construction system and the security of the inhabitants.

In the proposed system, the portion of the wall constituted by the rammed earth would work essentially for vertical loads. However, the characteristics of the timber reinforcement system (spacing and section of the timber posts) are calculated in such a way as to provide the wall with greater resistance against dynamic horizontal forces, increasing the maximum bending moment bearable by the section. Additionally, the auxiliary surface reinforcement in nylon/polyester ropes, solidarized to the timber skeleton and tensioned in such a way as to confine the earth wall, allows protecting against out-of-plane collapse mechanisms. Finally, the use of a finishing layer allows incorporating and protecting the surface reinforcement system in nylon/polyester ropes from the degradation caused by the exposition to atmospheric agents and especially to ultraviolet radiation.

The building system proposed inherits technical knowledge developed in highly seismic areas of our planet and integrates it with a logic strongly linked to the industrial production of natural-based materials and the optimisation of the building process. Figures 2-4 show, respectively: detailed plans, a three-dimensional view of the adopted reinforcing system and the prototype wall for the validation of the constructive process. The executive phases of the production process are described below in detail.

\subsubsection{Solid Ground Floor}

1. Excavation for the footing;

2. Installation of the cast concrete;

3. Waterproofing layer, e.g., made of polyethylene sheets (in the case of particularly humid soils or soils close to aquifers);

4. Reinforced concrete L-shaped footing; it must protrude from the ground level by at least $30 \mathrm{~cm}$ to protect the rammed earth wall from flooding phenomena and the rebound of rainwater. At the top, on the inner side, there will be a fold at least $20 \mathrm{~cm}$ deep to support the beams of the horizontal base closure;

5. Creation of a drainage crawl space on the external side of the footing;

6. Installation of the beams of the horizontal base closure (after waterproofing the heads of the beams);

7. Installation of the floor excluding the finishing layer;

8. Fixing of the bottom timber ring beam to the footing. 
a)

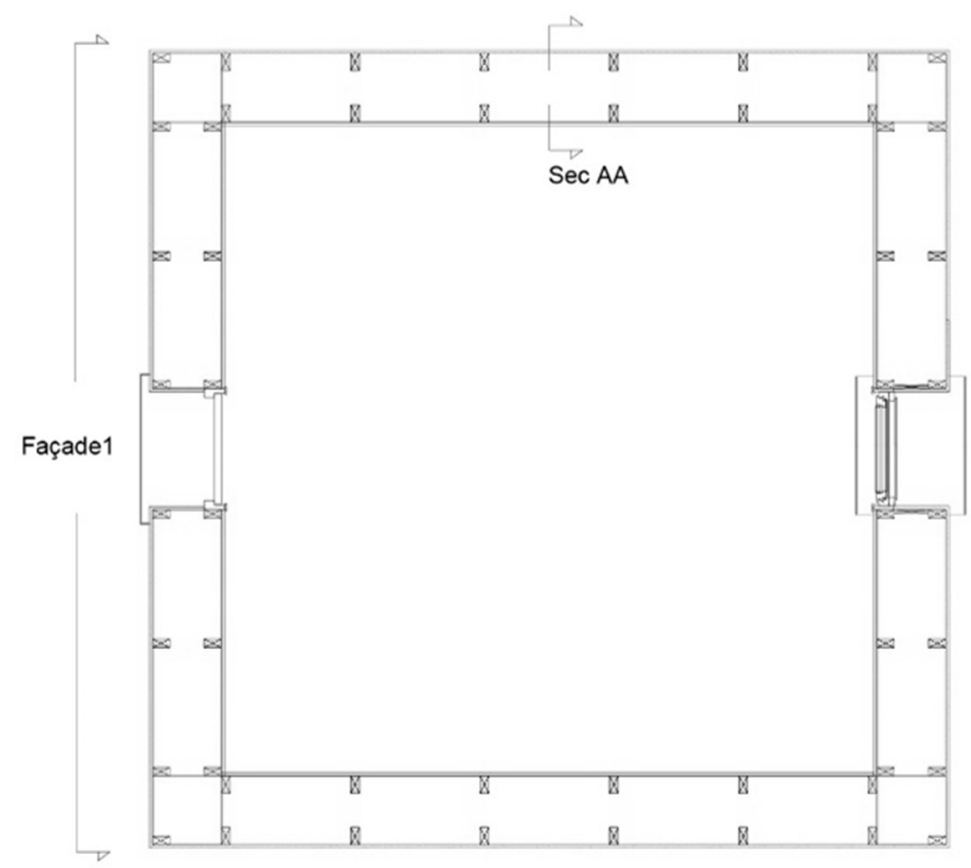

b)
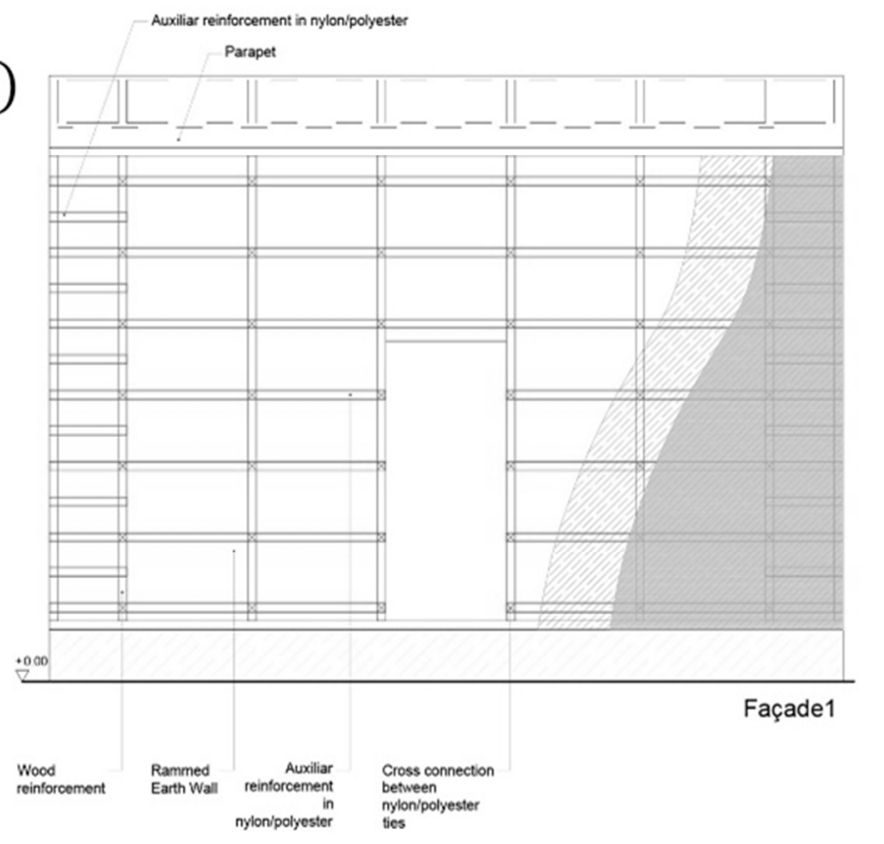

d)
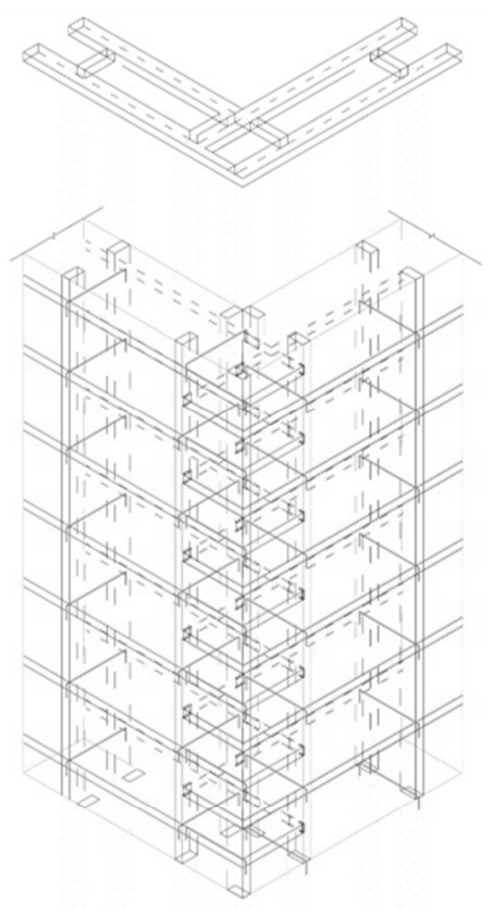

c)
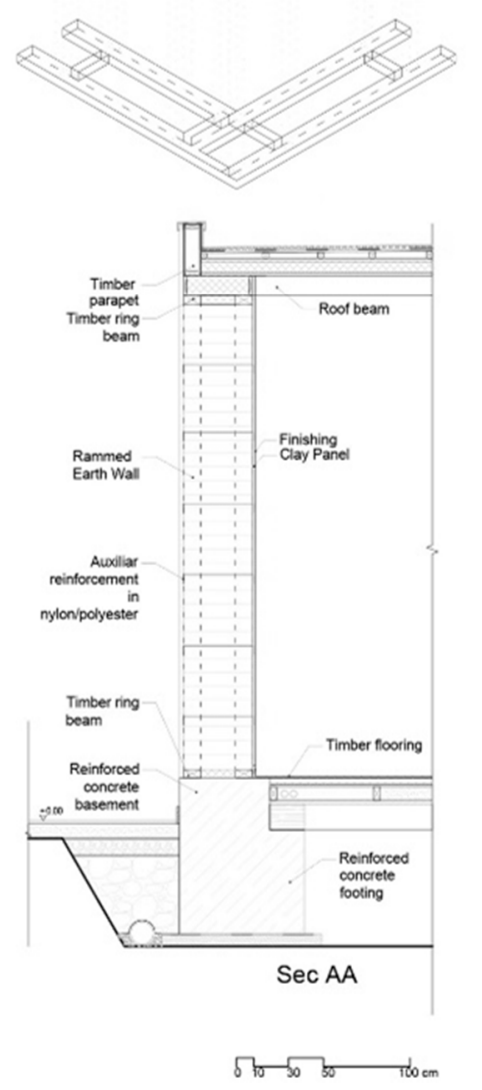

Figure 2. Graphical elaborations of the proposed constructive system: (a) plan, (b) façade, (c) vertical section and (d) corner axonometry with detail of nylon/polyester reinforcement. 


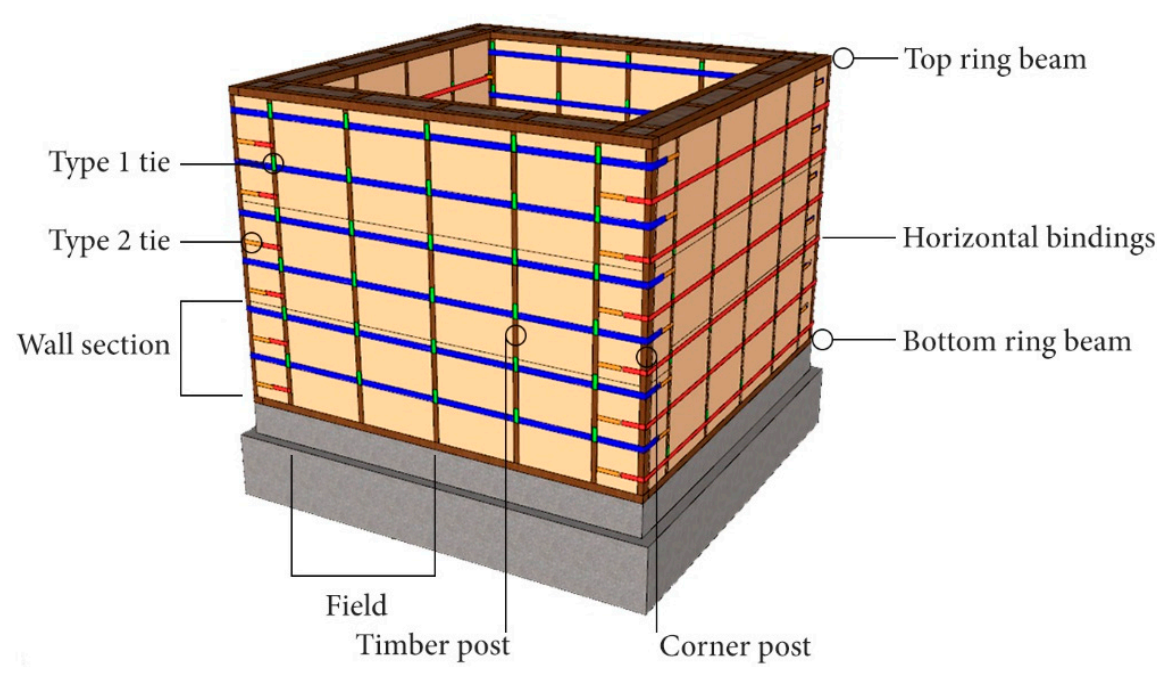

Figure 3. Three-dimensional reconstruction of the reinforcement system.

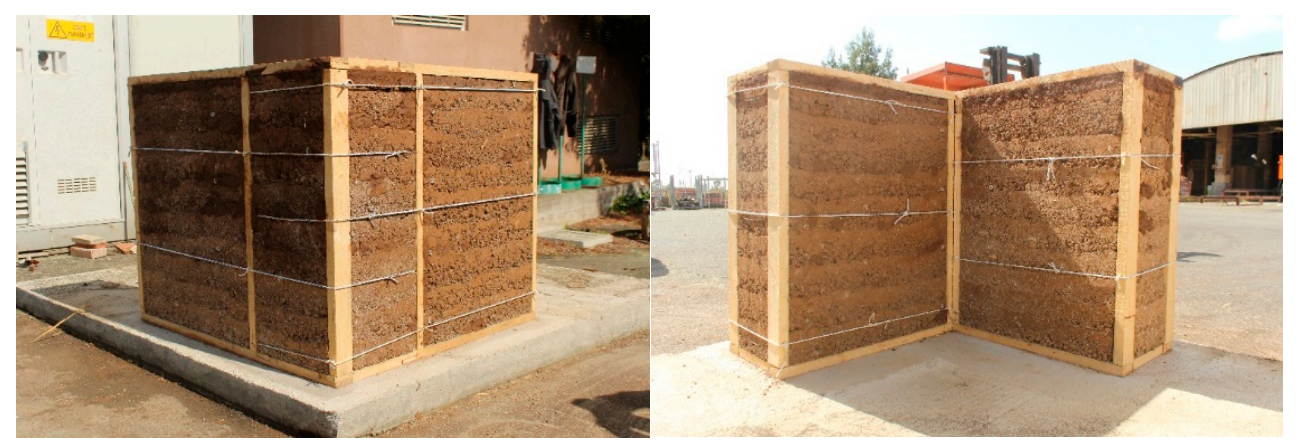

Figure 4. Construction of a prototype wall for the validation of the constructive process: view of the corner from the outside (image on the left) and the inside (image on the right).

\subsubsection{Rammed Earth Wall}

1. Connection of the timber posts to the bottom ring beam using steel L-squares. These posts have slots along their entire height, spaced vertically by approx. $30-40 \mathrm{~cm}$, for the passage of nylon/polyester type 1 ties;

2. Installation of the nylon/polyester type 1 ties for each pair of posts, starting from the lower part of the wall, by making them protrude at least $20 \mathrm{~cm}$ from the slots of the posts to subsequently install and lock the formworks;

3. Installation of the formworks. The longitudinal panels are perforated at the points where the nylon/polyester ties pass through, and the ties are secured in the immediate vicinity of these points by means of clamps and/or buckles;

4. Insertion of the type 1 ties into the holes of the formwork, stretching and locking on the longitudinal panels of the formwork by anchoring the ties in the cleats/buckles;

5. Installation of type 2 ties next to the last couple of posts near the corner post, vertically offset by $15-20 \mathrm{~cm}$ in relation to ties type 1 ;

6. Solidarization of the pairs of timber posts, at their upper ends, by means of a flat ring to prevent them from tipping over during the compaction phase;

7. Pouring of the ready-mixed rammed earth material into the formwork in layers of $15-20 \mathrm{~cm}$ and ramming until they reach half of their height, by means of an electric or pneumatic compactor. The entire rammed earth section must reach a height of $90-100 \mathrm{~cm}$. Particular attention must be paid to the areas close to the ties during compaction;

8. Once the first section of rammed earth masonry is completed, phases from 2 to 7 are repeated for the rest of the wall, taking care of wetting the contact surfaces before starting the compaction procedure; 
9. Installation of horizontal nylon/polyester reinforcement system (bindings) and anchorage to type 2 ties;

10. Tensioning of the horizontal bindings by means of turnbuckles (later removed) or by means of sliding knots and fastening to the type 1 ties;

11. Repeat steps 9-10 for all the walls. The corner will then be confined by a double system of horizontal ropes from the two orthogonal walls.

\subsubsection{Roof Horizontal Closure}

1. Installation of the top ring beam to the head of the vertical posts by nailing or laterally by a straight plate;

2. Connection of the load-bearing beams of the roof by means of metal brackets to the ring beam; in particular, beams will be set back a few centimetres $(2-3 \mathrm{~cm})$ with respect to the external edge of the wall;

3. Installation of an external frame (made up of timber boards) in the space left empty by the roof beams;

4. Installation of an internal frame (made of timber boards placed between the ceiling beams) in the space left empty by the roof beams;

5. For the construction of the horizontal/inclined closure of the roof, it is recommended to use insulation with low water vapour resistance. For the horizontal closure of the roof, solutions that project slightly from the vertical plane of the wall, ventilated roofs or green roofs are preferred.

\subsubsection{Finishings}

Finishing can be carried out with dry or wet processing. The vertical scanning (timber posts) of the rammed earth masonry allows for the easy application of an internal counterwall that allows for the passage of the plant equipment. In addition, the presence of the timber posts favours the assembly of the support systems of an external cladding wall, which can include insulation. If plastering is preferred, it is advisable to use an earth-based render in the interior walls or lime-based plaster in the exterior ones, with fibrous body plaster in order to incorporate and protect the surface reinforcement system in nylon/polyester ropes. The finishing layer should be made of a breathable material.

\subsection{Extimation of Construction Time and Costs}

The constructive system presented here allows a considerable rationalisation of the construction process compared to other reinforced raw earth building systems $[27,45,46]$ since the installation of the structural reinforcement elements (timber posts and ropes ties) takes place before the pouring and ramming of the material and not after. Moreover, this choice is advantageous for the integrity of the structure because the solid walls are not drilled (a posteriori) to insert transverse reinforcement elements, as provided by other procedures $[5,45,46]$. Furthermore, unlike other investigations using reinforcing elements placed inside the masonry section $[7,9,10,27]$, our system consisting of flexible elements does not hinder the compaction of the earth material.

It is estimated that with the proposed construction system, to realise $1 \mathrm{~m}^{2}$ of $40 \mathrm{~cm}$ thick reinforced walls, with the help of pneumatic tools for compaction and including the time of installation and connection of the anti-seismic reinforcing devices, about $3 \mathrm{~h}$ are required. According to current literature, for the realisation of $1 \mathrm{~m}^{3}$ of rammed earth, it takes about $6 \mathrm{~h} / \mathrm{man}$ operating according to evolved mechanised procedures and $10 \mathrm{~h} / \mathrm{man}$ for handcrafted procedures [47]. In this sense, our technology construction times are in line with those of common contemporary rammed earth constructions, but it is worth noting that the latter does not provide for the use of seismic-resistant reinforcement as timber posts and ropes.

The estimated cost for this technology is $700 \mathrm{EUR} / \mathrm{m}^{2}$ for a $40 \mathrm{~cm}$ thick rammed earth wall, consistent with costs provided by common rammed earth construction enterprises [48-50] but with the advantage of installing, at the same time, the wall and its 
reinforcing structure (integrated with the formwork system) made with sustainable, recycled, recyclable and natural building materials. In addition, the use of soil quarried in situ, or excavated for footing construction, would allow for a reduction in at least half of the costs.

\subsection{Thermal Performance Results}

As abovementioned, an accurate thermal dynamic analysis was performed on a representative rammed earth building in Mediterranean climate, to evaluate and compare the thermal behaviour of a naturally insulated rammed earth envelope and an uninsulated one in free-running conditions.

The following Figures 5 and 6 show two graphs for two representative periods of 2019: the hottest summer week (28 July-1 August) and the coldest winter (7-11 December) week. In both figures, dry bulb outdoor temperature $\left(\mathrm{T}_{\mathrm{o}}\right)$, indoor and outdoor surface temperatures (respectively $\mathrm{T}_{\mathrm{si}}$ and $\mathrm{T}_{\mathrm{so}}$ ), and average indoor air temperatures $\left(\mathrm{T}_{\mathrm{a}}\right)$ profiles are depicted. These profiles refer to the uninsulated rammed earth configuration (using only bioclimatic improvement strategies such as roof overhangs and natural ventilation) and to an insulated one (using both the abovementioned bioclimatic strategies and an insulation layer on the exterior side of the rammed earth wall). All the simulations are run under free-running conditions (in the absence of an HVAC system).

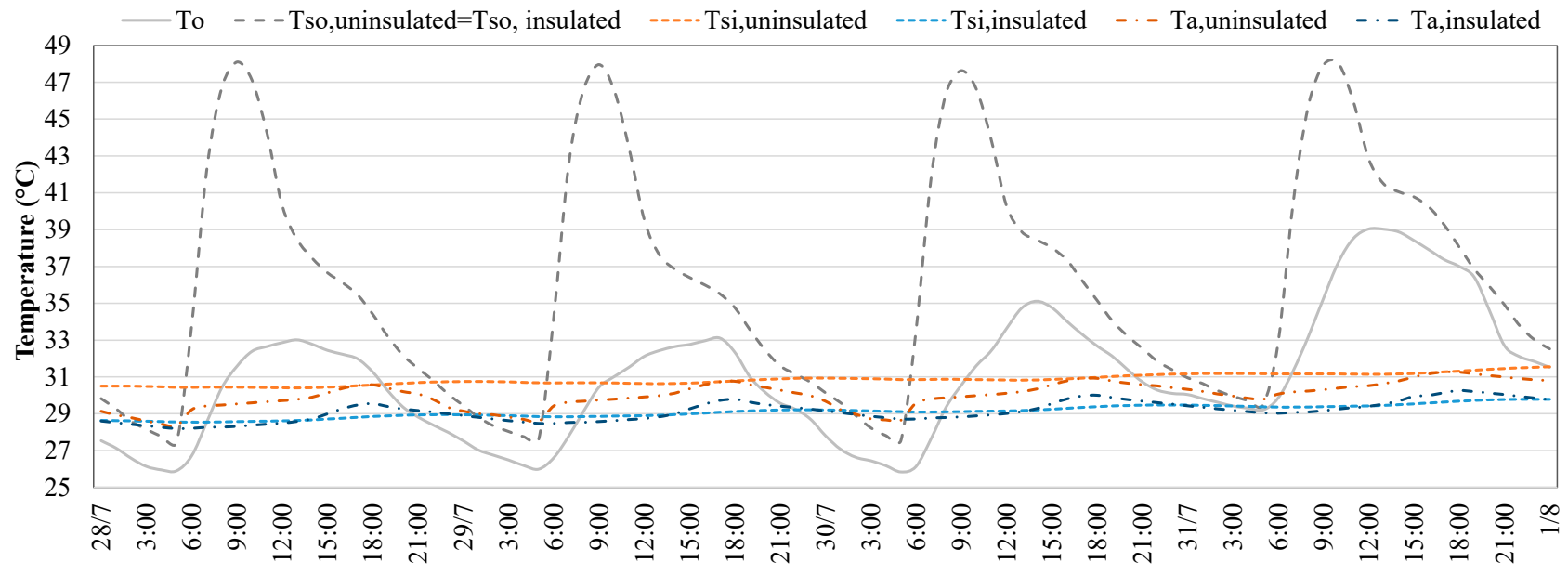

28 July - 1 August (East Room)

Hours

Figure 5. Temperature profiles from 28 July to 1 August in free-running conditions.

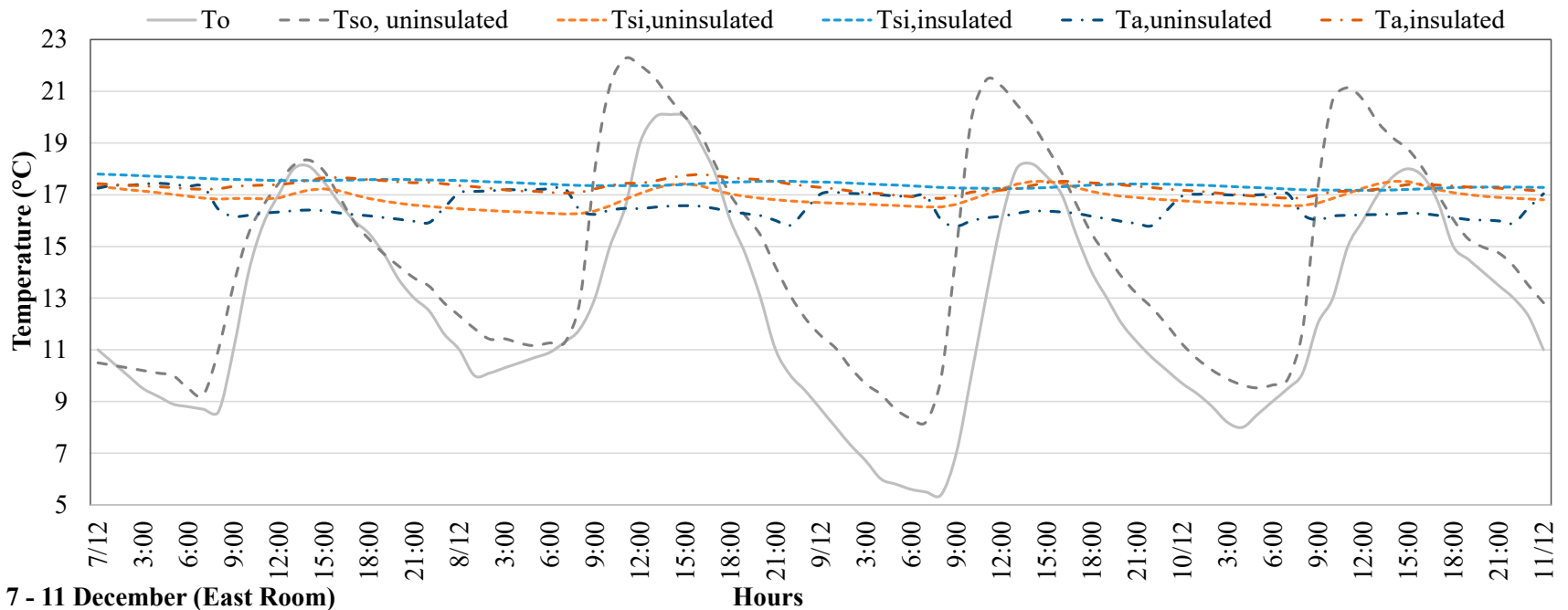

Figure 6. Temperature profiles from 7 December to 11 December in free-running conditions. 
As can be seen from Figure 5, given a profile of outdoor temperature $\left(T_{0}\right)$ and outdoor surface temperature $\left(\mathrm{T}_{\mathrm{so}, \text { uninsulated }}=\mathrm{T}_{\mathrm{so} \text {,insulated }}\right)$, the indoor surface temperature profile of the insulated case $\left(\mathrm{T}_{\mathrm{si}}\right.$,insulated $)$ is on average $1.77^{\circ} \mathrm{C}$ lower than the uninsulated case $\left(\mathrm{T}_{\mathrm{si}, \text { uninsulated }}\right)$ throughout the period considered. Moreover, the maximum indoor air temperature values in the insulated case $\left(\mathrm{T}_{\mathrm{a}}\right.$,insulated $)$ are always below $30{ }^{\circ} \mathrm{C}$ and on average $1{ }^{\circ} \mathrm{C}$ lower than those in the uninsulated case $\left(\mathrm{T}_{\mathrm{a}}\right.$,uninsulated $)$. During early mornings (5:00 a.m.), the minimum indoor air temperature values in the insulated case are on average $0.37^{\circ} \mathrm{C}$ lower than in the uninsulated case. In the thermally insulated case, a more stable thermal behaviour is generally observed regarding the indoor air temperature profiles.

Observing the graph in Figure 6 allows us to make interesting considerations. Given the profiles of outdoor temperature $\left(T_{0}\right)$ and outdoor surface temperature $\left(T_{s o, \text { uninsulated }}\right.$ $\left.=\mathrm{T}_{\mathrm{so} \text {,insulated }}\right)$, the profile of indoor surface temperatures in the insulated case $\left(\mathrm{T}_{\mathrm{si}, \text { insulated }}\right)$ is almost always above the profile of indoor surface temperatures in the uninsulated case $\left(\mathrm{T}_{\mathrm{si} \text {,uninsulated }}\right)$. The minimum values of indoor surface temperatures in the insulated case are on average $0.78{ }^{\circ} \mathrm{C}$ higher than those in the uninsulated case. Similar considerations can be made for the minimum values of indoor air temperature in the insulated case $\left(\mathrm{T}_{\mathrm{a} \text {,insulated }}\right)$, which are on average $0.87^{\circ} \mathrm{C}$ higher than in the uninsulated case $\left(\mathrm{T}_{\mathrm{a} \text {, uninsulated }}\right.$ and always above $17^{\circ} \mathrm{C}$.

The thermal performance validation herein presented showed the feasibility of using massive rammed earth walls in Mediterranean climates to ensure adequate indoor conditions. In particular, the analysis showed that during the summer season, the rammed earth material used for the envelope behaves as a thermal flywheel and remarkably dampens the incoming heat wave, keeping the curve of the inner surface temperature almost constant compared to the outdoor one. As we saw, the combination of bioclimatic design strategies using natural night cross-ventilation and overhangs to shadow outdoor walls allows for the maintenance of the indoor air temperature below $30^{\circ} \mathrm{C}$, but this value can be further reduced by about $1{ }^{\circ} \mathrm{C}$ by the addition of a thin layer of insulation. It is confirmed that the use of insulation also improves performances in the winter season by maintaining an average indoor air temperature of $17^{\circ} \mathrm{C}$ with an increase of $0.87^{\circ} \mathrm{C}$ compared to the uninsulated case.

\section{Conclusions and Final Remarks}

This contribution aimed at identifying an innovative constructive system in reinforced rammed earth characterised by low energy consumptions and specifically designed for high seismic risk territories. This constructive system is currently filed for a patent application.

The specificity of the constructive system is substantiated in the strong ecological connotation, in the high performance in terms of resistance to seismic phenomena, in the low energy consumption resulting from the characteristics of the designed envelope and in the reduced time and cost of implementation by virtue of the constructive process's optimisation.

The building system herein proposed inherits technical knowledge developed in highly seismic areas of our planet and integrates it with a logic that is strongly linked to the industrial production of natural-based building materials and to the optimisation of the building process. The comparison with other previously studied, commercialised, or patented systems highlights how the proposed technology, combining basic natural, recycled and low-cost building materials, simplifies the integration between the construction process of rammed earth walls and the installation of anti-seismic reinforcement systems.

Finally, the thermal performance validation in free-running conditions (namely, without the use of the HVAC system for heating and cooling) showed the good effects of using solid rammed earth walls in Mediterranean climates, especially in summer conditions. The use of earth walls with superior thermal inertia, together with bioclimatic strategies as natural night cross-ventilation and overhangs, succeeds in mitigating the effects of the extremely warm temperatures of Mediterranean summers. Moreover, the use of an additional 
thin insulation layer can help in further improving indoor air and surface temperatures and, therefore, the resulting thermal comfort, especially in the winter season.

The possible commercial outlets of the proposed building system are identified within the field of bio-architecture, with special reference to buildings made of natural and/or recycled materials. Moreover, the use of this solution responds to correct and responsible ecological thinking.

The proposed solution combines the environmental need (satisfied by the use of the rammed earth technology) with the one related to the resistance to dynamic actions (guaranteed by the reinforcement system designed) so as to propose a construction system that is effective in seismic areas, as many countries in the world are. At the same time, this system ensures satisfactory thermal and energy performance and is designed to ensure low construction costs and times as well as controlled performance responses. It should be noted that, in fact, the possibility of prefabricating the mixed design of the earth, together with the definition of a protocol for the structuring of the production and construction process, allows obtaining a system characterised by quantitatively defined performances, an uncommon circumstance for rammed earth construction.

Future works should focus on the in-depth study of the mechanical, thermal and durability performances of the proposed constructive system by the realisation of fullscale tests or by the construction of prototype buildings. Moreover, in order to prove the environmental benefits of using this type of technology, it is important to perform a life cycle analysis accounting for materials processing, manufacture, distribution and use and to compare it to conventional steel or RC buildings' environmental impact.

\section{Patents}

Patent with application No. 102021000006644 is pending.

Author Contributions: Conceptualisation, G.G. and R.C.; methodology, G.G., R.C., F.N. and M.C.; software, F.N. and M.C.; validation, F.N., R.C. and M.C.; formal analysis, G.G.; investigation, G.G.; resources, R.C.; data curation, G.G.; writing—original draft preparation, G.G.; writing—review and editing, R.C., F.N. and M.C.; visualisation, G.G.; supervision, R.C.; project administration, R.C.; funding acquisition, R.C. All authors have read and agreed to the published version of the manuscript.

Funding: This research received no external funding.

Institutional Review Board Statement: Not applicable.

Informed Consent Statement: Not applicable.

Acknowledgments: The authors would like to acknowledge the Centro Tierra research group for providing the equipment and the base material to realise the comparative dynamic test. The authors would like to acknowledge the Guglielmino Soc. Coop. for providing the base materials for the research and hosting the research group during the construction of the prototype wall.

Conflicts of Interest: The authors declare no conflict of interest.

\section{References}

1. P8_TA(2019)0220, Relazione Strategica Annuale Sull'attuazione e la Realizzazione Degli Obiettivi di Sviluppo Sostenibile, Risoluzione del Parlamento Europeo del 14 Marzo 2019 sul Cambiamento Climatico: Visione Strategica Europea a Lungo Termine per Un'economia Prospera, Moderna, Competitiva e Climaticamente Neutra in Conformità Dell'accordo di Parigi (2019/2582(RSP)). Available online: https:/ / www.europarl.europa.eu/doceo/document/TA-8-2019-0220_IT.html (accessed on 23 June 2021).

2. Direttiva UE 2018/2002 del Parlamento Europeo e del Consiglio dell'11 dicembre 2018, che Modifica La Direttiva 2012/27/UE Sull'efficienza Energetica. Available online: https:/ / eur-lex.europa.eu/legal-content/IT/TXT/PDF/?uri=CELEX:32018L2002\& from $=\mathrm{EN}$ (accessed on 23 June 2021).

3. Bollini, G. Terra Battuta: Tecnica Costruttiva e Recupero; Linee Guida per la Procedura di Intervento, Edicom Edizioni: Milano, Italy, 2013.

4. Giuffrida, G.; Caponetto, R.; Nocera, F. Hygrothermal Properties of Raw Earth Materials: A Literature Review. Sustainability 2019, 11, 5342. [CrossRef] 
5. Norma, E.080 Diseño y Construcción con Tierra Reforzada, Ministerio de Vivienda, Construcción y Saneamiento; El Peruano: Lima, Peru, 2017; Available online: https:/ / procurement-notices.undp.org/view_file.cfm?doc_id=109376 (accessed on 25 October 2021).

6. Jorquera Silva, N.; Cisternas Olguín, R. El tabique-adobillo, una técnica sismorresistente de Valparaíso, in Terra Lyon 2016. In Proceedings of the XIIe Congrès Mondial sur les Architectures de Terre, Lyon, France, 11-14 July 2016; Joffroy, T., Guillaud, H., Sadozaï, C., Eds.; CRAterre: Villefontaine, France, 2018.

7. Bravo Valenzuela, R.J. Muro Estructural con una Estructura Exogena a su eje Longitudinal Para Posibilitar su Relleno Interior en Obra. WO 2016/205968, 29 December 2016.

8. Estévez Rodriguez, A.; Martín-Lara Moreno, S. Edificio Modular Mixto de Entramado de Madera y Tapial. Patent No. ES 1091631 U, 18 October 2013.

9. Krayenhoff, M. Formwork and Method for Constructing Rammed Earth Walls. Patent No. US 8,375,669 B2, 19 February 2013.

10. Ward, T.; Grill, J. Post-Tensioned Rammed Earth Construction. Patent No. US 7,033,116 B1, 25 April 2006.

11. Dipasquale, L.; Mecca, S. Local seismic culture in the Mediterranean region. In Seismic Retrofitting: Learning from Vernacular Architecture; Correia, M., Lourenço, P.B., Varum, H., Eds.; Taylor \& Francis Group: London, UK, 2015; ISBN 978-1-138-02892-0.

12. Galassi, S.; Ruggieri, N.; Tempesta, G.; Zinno, R. Stability and Stiffness Contribution of the Masonry in the Borbone Anti-Seismic System. In Proceedings of the 9th International Masonry Conference, Guimarães, Portugal, 7-9 July 2014.

13. Stellacci, S.; Ruggieri, N.; Rato, V. Gaiola vs. Borbone System: A Comparison between 18th Century Anti-Seismic Case Studies. IJAH 2016, 10, 817-828. [CrossRef]

14. Poletti, E.; Vasconcelos, G.; Oliveira, D. Influence of Infill on the Cyclic Behaviour of Traditional Half-Timbered Walls. In Proceedings of the Rehabilitation and Restoration of Structures International Conference, Chennai, India, 13-16 February 2013.

15. Tonna, S.; Ruggieri, N.; Chesi, C. Comparison between two traditional earthquake proof solutions: Borbone and Lefkada Timber-frame systems. J. Archit. Eng. 2018, 24, 04018030. [CrossRef]

16. Gülkan, P.; Langenbacht, R. The Earthquake Resistance of Traditional Timber and Masonry Dwellings in Turkey. In Proceedings of the 13th World Conference on Earthquake Engineering, Vancouver, BC, Canada, 1-6 August 2004; p. 2297.

17. Giuffrida, G.; Caponetto, R.; Cuomo, M. An overview on contemporary rammed earth buildings: Technological advances in production, construction and material characterization. IOP Conf. Ser. Earth Environ. Sci. 2019, 296, 012018. [CrossRef]

18. Windstorm, B.; Schmidt, A. A Report of Contemporary Rammed Earth Construction and Research in North America. Sustainability 2013, 5, 400-416. [CrossRef]

19. Von Mag, A.; Rauch, M. Rammed earth walls and its industrialization (formworks and ramming systems). Informes de la Construcción 2011, 63, 35-40.

20. Dahmen, A.J.; Muñoz, B.J.F. Modular rammed earth masonry block. In Rammed Earth Construction: Cutting-Edge Research on Traditional and Modern Rammed Earth, Proceedings of the First International Conference on Rammed Earth Construction, Perth and Margaret River, WA, Australia, 10-13 February 2015; Ciancio, D., Beckett, C., Eds.; Taylor \& Francis Group: London, UK, 2015; ISBN 978-1-138-02770-1.

21. Krayenhoff, M. Rammed Earth Thermodynamics. In AA.VV. Rammed Earth Construction; Ciancio, D., Beckett, C.T.S., Eds.; Taylor \& Francis Group: London, UK, 2015.

22. New Zealand Standard 4299: 1998. Earth Buildings Not Requiring Specific Design; Standard New Zealand: Wellington, New Zealand, 1998.

23. Proposal RB299-19. Appendix U. Cob Construction (Monolithic Adobe); 2018 International Residential Code: Brea, CA, USA, 2019; Available online: https://cobcode.s3.amazonaws.com/RB299-19_IRC_ProposedAppendixU_CobConstruction.pdf (accessed on 25 October 2021).

24. Miccoli, L.; Müller, U.; Pospíšil, S. Rammed Earth Walls Strengthened with Polyester Fabric Strips: Experimental Analysis under In-Plane Cyclic Loading. Constr. Build. Mater. 2017, 149, 29-36. [CrossRef]

25. Neves, C.; Borges Faria, O. Técnicas de Construcción con Tierra, Bauru-SP, FEB-UNESP/PROTERRA. 2011. Available online: https: / /redproterra.org/wp-content/uploads/2020/05/4a_PP-Tecnicas-de-construccion-con-tierra_2011.pdf (accessed on 23 June 2021).

26. Houben, H.; Guillaud, H. Traité de Construction en Terre; Éditions Parenthèses: Marseille, France, 2006.

27. Tejada Schmidt, U.; Mendoza Garcia, A.; Torrealva Davila, D. Uso del Tapial en la Construcción, 2016, Servicio Nacional de Capacitación para la Industria de la Construcción SENCICO. Available online: https: / issuu.com/catalogosencico/docs/libro_ sencicotapial_mejorado (accessed on 23 June 2021).

28. San Bartolomè, A.; Quiun, D. Construccion con Tapial; ININVI Instituto Nacional de Investigacion y Normalizacion de la Vivienda: Lima, Peru, December 1989.

29. Tantaleán Altamirano, C.J.J.C. Desarrollo de un Diseño Estructural por Esfuerzos de Trabajo (det) en Viviendas de Tapial de 1 Piso. Thesis Pucp. Bachelor's Thesis, Pontificia Universidad Católica del Perú, Lima, Peru, 2018. Available online: https: / / tesis.pucp.edu.pe/repositorio/handle/20.500.12404/12810 (accessed on 25 October 2021).

30. Tripura, D.D.; Singh, K.D. Axial Load-Capacity of Bamboo-Steel Reinforced Cement Stabilised Rammed Earth Columns. Struct. Eng. Int. 2019, 29, 133-143. [CrossRef]

31. Minke, G. Building with Earth: Design and Technology of a Sustainable Architecture; Birkhäuser: Berlin, Germany, 2006.

32. Blondet, M.; Vargas, J.; Tarque, N.; Iwaki, C. Construcción sismorresistente en tierra: La gran experiencia contemporánea de la Pontificia Universidad Católica de Peru. Informes de la Construcción 2011, 63, 41-50. [CrossRef] 
33. Blondet, M.; Vargas, J.; Sosa, C.; Soto, J. Seismic simulation tests to validate a dual technique for repairing adobe historical buildings damaged by earthquakes. In Proceedings of the Kerpic'13-New Generation Earthen Architecture: Learning from Heritage International Conference, Istanbul, Turkey, 11-14 September 2013; Available online: http:/ / www.syzmingesa.com/preview / 2/seismic-simulation-tests-to-validate-a-dual-technique-for-repairing-adobe-historical-buildings-damaged-by-earthquakes(accessed on 25 October 2021).

34. Blondet, M.; Vargas, J.; Sosa, C.; Soto, J. Using mud injection and an external rope mesh to reinforce historical earthen buildings located in seismic areas. In Proceedings of the SAHC2014-9th International Conference on Structural Analysis of Historical Constructions, Mexico City, Mexico, 14-17 October 2014.

35. Blondet, M.; Rubiños, A. Communication Tools for the Construction of Safe and Decent Earthen Houses in Seismic Areas. In Proceedings of the Human Development \& Capability Association Conference, Athens, Greece, 2-5 September 2014.

36. Serrano, M.; Blondet, M.; Rubiños, A.; Mattsson, E. Sustainable dissemination of earthquake resistant construction in the Peruvian Andes. Sustain. Sci. Pract. Policy 2016, 12, 22-33. [CrossRef]

37. Blondet, M.; Vargas, J.; Tarque, N.; Soto, J.; Sosa, C.; Sarmiento, J. Seismic reinforcement of earthen constructions. In Proceedings of the 16th World Conference on Earthquake Engineering, Santiago de, Chile, 9-13 January 2017; p. 2168.

38. Available online: http://investigacion.pucp.edu.pe/grupos/ctierra/noticia-evento/emergencia-orduna-sismo-6-3-richter/ (accessed on 23 June 2021).

39. Giuffrida, G.; Detommaso, M.; Nocera, F.; Caponetto, R. Design optimisation strategies for solid rammed earth walls in Mediterranean climates. Energies 2021, 14, 325. [CrossRef]

40. Ascione, F.; De Rossi, F.; Vanoli, G.P. Energy retrofit of historical buildings: Theoretical and experimental investigations for the modelling of reliable performance scenarios. Energy Build. 2011, 43, 1925-1936. [CrossRef]

41. Cornaro, C.; Puggioni, V.A.; Strollo, R.M. Dynamic simulation and on-site measurements for energy retrofit of complex historic buildings: Villa Mondragone case study. J. Build. Eng. 2016, 6, 17-28. [CrossRef]

42. Gagliano, A.; Nocera, F.; Patania, F.; Moschella, A.; Detommaso, M.; Evola, G. Synergic effects of thermal mass and natural ventilation on the thermal behaviour of traditional massive buildings. Int. J. Sustain. Eng. 2016, 35, 411-428. [CrossRef]

43. Nocera, F.; Caponetto, R.; Giuffrida, G.; Detommaso, M. Energetic Retrofit Strategies for Traditional Sicilian Wine Cellars: A Case Study. Energies 2020, 13, 3237. [CrossRef]

44. Università degli Studi di Catania e Guglielmino Società Cooperativa a R.L. Sistema Costruttivo Antisismico: Tecnologia e Processo di Produzione. Domanda di Brevetto No. 102021000006644, 19 March 2021.

45. Rodríguez-Larraín, S.; Alvariño, M.; Onnis, S.; Wieser, M.; Jimenez, C.; Meli, G.; Vargas Neumann, J.; Sosa, C. Manual del Promotor Técnico Para la Construcción de la Vivienda Altoandina Segura y Saludable, Concytec 2016, Proyecto Transferencia Tecnológica para la Vivienda Altoandina 2014-2016. Available online: https:/ /issuu.com/centrotierra/docs/1._manual_del_ promotor_t_cnico (accessed on 23 June 2021).

46. Rodríguez-Larraín, S.; Montoya, T.; Gíl Zacarías, S.; Onnis, S.; Vargas Neumann, J. Manual de la Técnica Constructiva ValidadaDescripción del Proceso por Etapas de la Construcción del área Piloto “Los Domingos” en la Hacienda Santa María en Tarma con la Técnica del Tapial Mejorado, Ed. 2014, Proyecto N 187- Fincyt-Fidecom-Pimen 2012. Available online: https:/ / investigacion. pucp.edu.pe/grupos/ctierra/publicacion/manual-de-la-tecnica-constructiva-validada-tapial-tarma/ (accessed on 23 June 2021).

47. Scudo, G.; Narici, B.; Talamo, C. Costruire con la Terra; Ed. Sistemi Editoriali: Milano, Italy, 2001.

48. How Much Does Rammed Earth Cost? Available online: https://www.rammedearthenterprises.com.au/rammed-earth-cost/\#: $\sim\{\}:$ text=The $\% 20$ price $\% 20$ range $\% 20$ for $\% 20$ the,size $\% 2 C \% 20$ design $\% 2 C \% 20$ finishes $\% 20$ etc (accessed on 23 June 2021).

49. What Is the Cost per Square Foot of Different Earth Building Methods? An Overview of Natural, Eco-Friendly, Earthen Architecture Traditions. Available online: https: / mudman.blog/2017/04/18/what-is-the-cost-per-square-foot-of-differentearthen-building-styles / (accessed on 23 June 2021).

50. Custom Homes and Cost. Available online: https://www.earthhomes.co.nz/What+we+do/Custom + Homes+and + cost.html (accessed on 23 June 2021). 